\title{
Container Flexitank's Life Cycle Analysis to Promote Environmental Sustainability
}

\author{
Breno Gregório Lima ${ }^{1}$, Camila Papa Lopes ${ }^{2}$ \\ ${ }^{1}$ Stricto Sensu Institute of Post-Graduation in Law, Catholic University of Santos, Santos City, Brazil \\ ${ }^{2}$ Institute of Human Sciences, Paulista University, Santos City, Brazil
}

Email address:

bglima@hotmail.com (B. G. Lima), camilapapa@hotmail.com (C. P. Lopes)

\section{To cite this article:}

Breno Gregório Lima, Camila Papa Lopes. Container Flexitank's Life Cycle Analysis to Promote Environmental Sustainability. International Journal of Environmental Monitoring and Analysis. Vol. 5, No. 5, 2017, pp. 128-133. doi: 10.11648/j.ijema.20170505.12

Received: June 10, 2017; Accepted: September 29, 2017; Published: October 27, 2017

\begin{abstract}
The present discussion addresses an environmentally relevant issue regarding the use of flexitank as a low cost, easy operation and safe option on container assiduity and physical integrity. However, it is questioned about disposal of this equipment. The objective is investigating flexitank impact disposal on global environment and relevant legislation. Compilation research based on bibliographic review of flexitank life cycle analysis in global container market. Analysis evidences flexitank de-characterization as packaging, since it constitutes a container accessory, deserves special attention of law to define a legal parameter of its use in a sustainable way, providing for situations such as reuse or material recycling, through characterization life cycle legal of flexitank which will certainly favor environment and international maritime law in containerized cargo transport.
\end{abstract}

Keywords: Flexitank, Product Life Cycle, Environmental Sustainability, Maritime Legal Instruments

\section{Introduction}

[1] understands that people need to encourage both general legal instruments by articulating intergenerational rights and obligations towards our planet.

For the author, international regimes are important to manage or coordinate measures for management of certain natural resources or environmental pollutants. They facilitate information development and exchange, make it more difficult for a party to defect, as there are costs involved, and can contribute to new standards development.

The emergence of new standards based on sustainable development is in accordance with need to evolve legal instruments related to international shipping, especially on legal standard discussion dealing with container and specifically in this analysis, deal with flexitank, a container equipment.

According to [2], a scholar on subject of container transport, several transportation systems can be used to transport containers from one destination to another. The author comments on means of transport used as well as increase of carrying capacity to ships.

This suggests a greater debate on subject with regard to resources used to optimize containers transport and thus to fulfill their essential function of cargo unitization.

According to Maritime Guide, an important report of port and equipment's innovation in Brazil, there will be implementation of new container weighing rule should change flow of cargo worldwide, but several countries still have doubts about its applicability and regulation. Working groups are organizing on all continents, with common purpose of stipulating internal procedures adapt regional markets to international rules established by International Maritime Organization (IMO).

The main objective of new, global rule is to ensure safer navigation, a necessity has been raised by SOLAS, IMO shipping safety committee, by instituting a mandatory Verified Gross Mass (VGM) declaration for each Container to be shipped. The start of new law is scheduled for July 1, 2017, when every shipowner should receive the certified weigh in advance to authorize or not the containers shipment. The difficulty is each country should determine its regulatory bodies to intervene locally and stipulate parameters to meet international requirements. 
In this discussion there is room for discussion on flexitanks life cycle as a way to insertion of international legislation to ensure sustainability of operations with this equipment.

As a method for conducting research, a compilation survey was used based on bibliographic review of flexitank law and life cycle analysis in global container market.

\section{Theoretical}

\subsection{Conteiner with Flexitank in International Law}

Although container has caused significant evolution in global cargo transportation, [3] analyze it has caused controversies in international trade, mainly in Maritime Law relation, legal discipline whose object is legal relations occur around the ships. Because container is considered to be part of ship that most transits dock, several issues arise from its handling, loading and unloading operations, among them Federal Revenue Service, port logistics bottlenecks due to inefficiency, malfunctions, among others.

The authors explain container is characterized as an ship accessory, container is products transport constructed of resistant material, capable of providing security, inviolability and speed, equipped with a customs security device meets legally prescribed technical conditions.

The container use expanded with exporters demand increase culminated in mechanisms for transit time reduction, operation costs and security increase in merchandise. Among these mechanisms, emergence of container varied types, classified according to cargo type they are able to carry, stand out.

Among them, highlight flexitank, which is configured as an equipment to transport products inside containers (Figures 1 and 2).

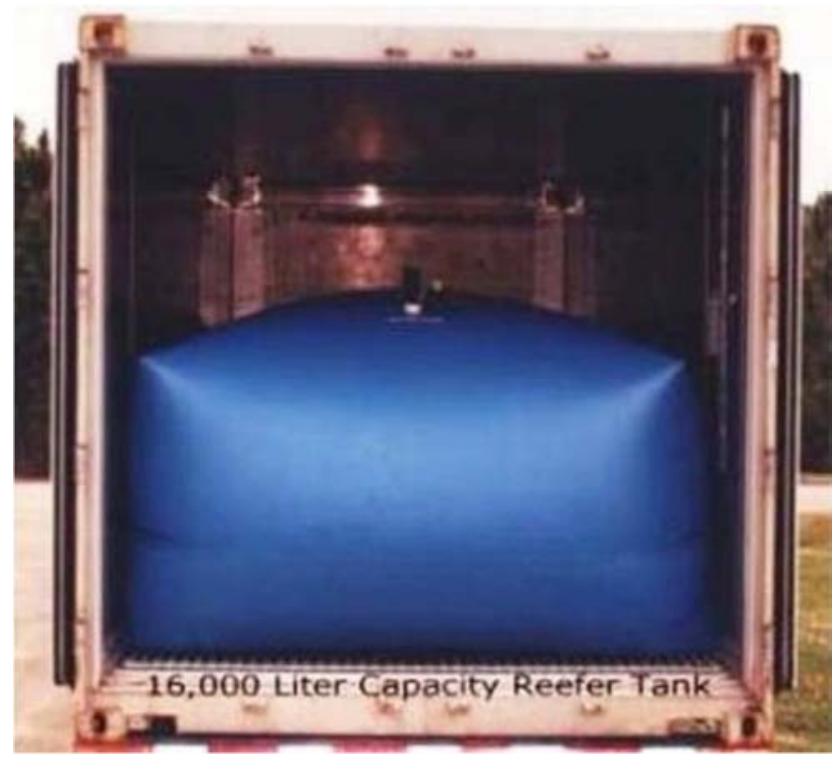

Source: www.flexitank.com

Figure 1. Flexitank.

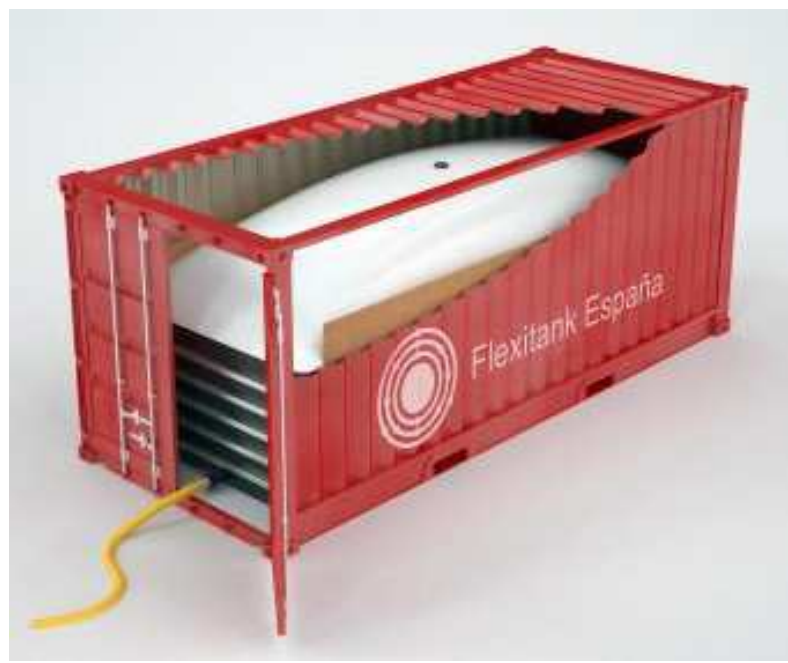

Source: www.flexitank.com

Figure 2. Flexitank in container

Its advantage is reduced cost in relation to other solutions adopted, such as Tank Containers (Isotanks). Tank Container is a type of container used to transport products or bulk liquids, gases, food and even dangerous carg.

These types of containers are also known as isotanks because they comply with ISO (International Organization for Standardization) standards.

The flexitank consists of a standard container, inside which is attached a flexible polyethylene tank called flexibag.

According to $[4,5]$ agents tend to be skeptical about flexitanks widely use, especially if products are potentially harmful to environment, however, its advantages use make it very competitive in current market. And tend to revert this skepticism, because its use makes dispensable need for mass storage intermediary, by its characteristics of simple availability throughout territory, has low acquisition cost, can be transported quickly by air, in addition to sea, The material is kept clean in tanks, there is no risk of contamination by other products, it has a vacuum seal, without oxidation, in case of product with a low acquisition cost, it allows increase of payload transported, there is no need for return, less complexity in loading and unloading operation and makes it simple to consolidate.

The author notes some shipowners deny permission to carry on their ships flexitank units, however, tendency is wide acceptance since documented proofs adequately as characteristics necessary to load them, thus representing an excellent alternative in charge transport.

Also [3] mention as flexitanks advantages their important role in normal and special transportation, which presents high convertibility and volume occupancy indicators. The authors evaluated by a score participation of several containers types and their characteristics, considering flexitank advantageous as adaptability of this equipment use.

Other solutions have been developed for products transport, such as Europalets, but flexitank is lower cost alternative and already adapted to containers reality currently, since it is used of established infrastructure functioning as an accessory of these. 
Among products categories commonly carried by flexitank are $[3,4]$ :

Non-hazardous chemicals: lactic acid, ricinoleic acid, additives, chlorine aluminum hydroxide, glycerin, paraffin, latex (natural and synthetic), oils and lubricants for automotive industry, printing ink, among others.

Food products: olive oil, sweeteners, emulsifiers, malt extract, vegetable oils (palm oil and others), fish oil, honey, drinking water, fruit concentrates, wine, must, sorbitol, among others.

A flexitank allows transporting between 10,000 and 24,000 liters, although usual models are those of 16,000, 18,000, 20,000, 22,000 and 24,000 liters. Generally higher capacity model is used, however for model choice and flexitank capability, the product density must be calculated.

Among most common flexitank sizes, by product type to be transported, are shown in Table 1.

Table 1. Relation Product Types and flexitank capacity.

\begin{tabular}{ll}
\hline Product & Flexitank Size \\
\hline Glycerin & 20.0001 \\
Wine & 24.0001 \\
Olive Oil & 22.0001 \\
Flexitank for transporting oil palm & 21.0001 \\
Flexitank for polyol transport & 19.0001 \\
Flexitank for latex transport & 19.0001 \\
\hline
\end{tabular}

Source: TIBA (2016)

\subsection{Sustainability Questions in Flexitank Use and Disposal}

The According to [1], sustainable development foresees commitment of fairness to future generations. This is in relation to resources availability and use.

This perspective began in 1972 at United Nations Stockholm Conference on Human Environment, which recognized global responsibility to "protect and improve" environment for both present and future generations.

In 1992, it was necessary to define and implement this commitment to future generations in environmentally sustainable development context.

Defined in Our Common Future report [6], sustainable development, or eco-development, concept:

It is a process of transformation directs resource exploration, investment, technological development and institutional change so they harmonize to increase present and future potential to meet human needs.

The concept of sustainable development was defined in Brundtland Report or "Our Common Future", developed by World Commission on Environment and Development, in 1987. To this report, sustainable development included two general aspects: needs and limitations. It is referred to a standard of living and sustainability goals discussion. It also states that determining factor needs are society and culture.

To Our Common Future report, sustainable development and eco-development concept is a transformation process directs resources exploitation, investments, technological development and institutional changes in order to harmonize to increase this potential and future, to meet human needs.
[7] analisys refeers to relationship between human capital and natural resources, initially in 1993, arguing about stance of rich and poor, north and south, where rich want to keep their consumption pattern and poor have as resources exploitation culture in a disorderly manner.

In 1993, Sachs speech also expounded about population explosion, but focused on movement of disorderly urbanization, particularly in South, suggesting need for development strategies. [7] considers sustainable development is related to consumption and proposes to be made political reforms change supply problems, with technology contribution and reorientation.

It also emphasizes one should not forget basic needs as a priority and it is necessary to reduce to acceptable levels of natural resources exploitation.

The analysis of sustainability has evolved towards perspective of sustainability dimensions must be balanced to speak in this concept application, among them, [7] mentions:

Social: search for an acceptable level of social homogeneity; Improvement in distribution of income, which should be more egalitarian; Improvement in employment / work conditions with life quality; Equal access to social resources and services;

Cultural: changes $\mathrm{X}$ continuity and balance between innovation and tradition and historical heritage;

Ecological: preservation of natural environment potential and biodiversity in renewable resources production; Limitation of non-renewable resources use;

Environmental: respecting self-purification ecosystems capacity;

Economic: balanced economic development; Food safety; Improvement in production capacity and resources; Autonomy in scientific and technological research; Integration into international economy.

Later, Sachs (2008) believes to be eco-development is required local participatory planning.

There is also dimensions dismemberment consider by [7] as a way to expand explanation and sustainability scope, as follows:

1) Social: deals with scope of social homogeneity reasonable level, with fair income distribution, full employment and / or self-employed with decent quality of life and equal access to resources and social services.

2) Cultural: considers changes within continuity (balance between respect for tradition and innovation), autonomy capacity for development of integrated and endogenous national project (as opposed to slavish copies of alien models) and self-confidence, combined with openness to world.

3) Ecological: refers to natural capital potential preservation in production of renewable resources and limiting non-renewable resources use.

4) Environmental: refers to respect and enhance self-purification of natural ecosystems capacity.

5) Territorial: addresses urban and rural settings balanced (elimination of urban slopes in public investment allocations), urban environment improving, overcoming 
inter-regional disparities and environmentally sound development strategies for ecologically fragile areas.

6) Economic: refers to intersectional balanced economic development, food security, continuous upgrading of production capacity tools, reasonable level of autonomy in scientific and technological research and sovereign insertion in international economy.

7) Politics (National): is democracy defined in terms of human rights universal appropriation, state capacity development to implement national project, in partnership with all entrepreneurs and social cohesion reasonable level.

8) Politics (International): is associated with effectiveness of UN war prevention system, peace guarantee and international cooperation promotion, North-South Package development based on equality principle (rules of game and sharing favoring responsibility of weaker partner), effective institutional control of international financial system and business, effective institutional control of precautionary principle application in environmental management and natural resources, negative global change prevention, biological diversity protection ( and cultural), the global asset management as common patrimony of mankind, effective system of international scientific and technological cooperation and partial elimination character of science and technology commodity, as well as ownership of common patrimony of mankind.

[1] further complements that planet have developed economic instruments to efficiently meet present generation needs, but these are not adequate to address equity issues with future generations.

The incorporation of externalities is intended to ensure benefits resulting from a proposed action outweigh costs and those who bear these costs are duly compensated.

However, in practice, it quantifies from present generation perspective. Environmental externalities are mainly focused on current generation costs has in air, water and soil use contaminated by industrial development, deforestation and other economic development aspects.

According to [1], international law has been fundamentally concerned with justice issues. Normative dimension that economic instruments implement are relevant in this analysis because, if there is a pretension to achieve intergenerational equity, it is essential to analyze normative relationship between generations.

It is necessary to observe how much there is a relation between sustainability debate and innovative equipment use in loads transport, which needs a specific legal parameter that addresses flexitank specific issues.

Acording to [8], Flexitank, besides offering safety and low cost, is ecologically correct - after use, it is discarded with the guidance of the regulatory agencies. Easy to store, does not take up much space and has a higher load capacity compared to drums. A company that works with flexitank, Allog, registered in 2016, growth in the use of isotanks and flexitanks of $18 \%$ among the company's customers, with a forecast of maintaining the advance between $20 \%$ and $30 \%$ in 2017.

International law has addressed intertemporal issues to relate present to past. In public law, it applies to territorial claims, rules of customary international law and treaties. In private law, this is reflected in time-choice issues such as conflict of laws rules.

Intertemporal issues also arise in procedural context rules established by international tribunals.

In order to encourage cooperation between countries and communities to meet obligations towards future generations, it is useful to develop and codify relevant intergenerational equity norms.

The flexitank operation follows a common procedure. Flexitank manufacturers were researched to describe loading and unloading process of flexitank $[3,4,5,7]$.

Initially, flexitank should be installed in a container, which should be performed only by qualified personnel and approved by equipment manufacturer. The installation process should be carried out in warehouses, container depots or other suitable to installation. It should be checked whether the container is in good condition, inside of container should be lined with protective material, then flexitank and respective bulkhead(s) will be inserted, finally a new check will be done to ensure cargo is in product condition for shipment.

At flexitank filling point, door on container right side is opened by inserting loading pump into valve, waiting for completion of loading / unloading work, about 30 minutes (depending on pump capacity and product viscosity to be inserted into bag).

After good condition of transport has been loaded and certified, it is carried out in accordance with legislation applicable to transport of general cargo.

One of relevant criteria currently adopted is need for flexitanks manufacturers to be approved by shipping lines and approved by Container Owners Association (COA) stress tests, which certifies flexitank chosen may be transported by road Safety.

The flexitank process of unloading occurs once it has reached its destination. In a similar process to loading, simply open right door, connect hose to discharge pump and respective flexitank valve and start operation, wait for it to empty. The process may take between 30 and 60 minutes depending on both pump capacity and product viscosity.

By its characteristics and, in order to avoid wastes, flexitank should be folded when it is almost empty. In this way remaining product is pushed to flexitank mouth to fully discharge it.

After it is empty, manufacturer, owner or flexitank person responsible or its agents remove it from container and destroy it - which must comply with local environmental regulations.

Currently for liquid bulk transport, manufacturers and shippers use disposable flexitanks, ensuring their customers are not loaded products contaminated with any residues from previous uses. 
Legally, there is no definition of flexitank as a container typology, what is currently the concept of unit of charge, a legal evolution of container concept proposed by Law n.6288 $/ 75$ defined container in its article 3 , in verbis:

Art. 3 The container, for all legal purposes, does not constitute products packaging, always being considered an equipment or accessory of transporting vehicle.

Single paragraph. The concept of container does not include vehicles, accessories or parts of vehicles and packaging, but comprises its specific accessories and equipment, such as trailers, boogies, racks, or shelves, cribs or modules, provided they are used as an integral container part.

Also, Decree $80.145 / 1977$, defines container in its art. $4^{\circ}$, in verbis:

Article 4 The container is made of resistant material, designed to provide products transport with security, inviolability and speed, with customs security devices and having to comply with technical and safety conditions foreseen by national legislation and international conventions Ratified by Brazil.

The definition of unit of charge is given by Law n.9611 / 98 in its article 24 , in verbis:

Article 24. For purposes of this Law, it is considered a unit of loading any equipment suitable for products unitization to be transported, subject to indivisible handling in all modes of transportation used in course.

Single paragraph. The cargo unit, its accessories and equipment do not constitute packaging and are integral parts of whole.

And its parameters of use in articles 25 and 26, in verbis:

Article 25. The cargo unit must meet technical and safety requirements required by international conventions recognized by Brazil and national legal and regulatory standards.

Article 26. It is free to enter and exit, in country, of cargo unit and its accessories and equipment, of any nationality, as well as its use in domestic transport.

Also, to [5, 8, 9], the Customs Regulation - Decree n. 6.759 / 09 (RA 2009), updated by Decree n. 7.213/ 10 acknowledged that entry into national territory of container is free. It should be noted in previous regulation, these units were subject to control from entry to exit. Such recognition is given in article 39 of the aforementioned standard (RA 2009):

Article 39. The entry and exit of cargo units and their accessories and equipment of any nationality, as well as their use in domestic transportation (Law No. 9,611 of February 19, 1998, Article 26).

(1) The regime of temporary admission or temporary export shall apply automatically to the goods referred to in the caput.

(2) The provision of information for the purposes of customs control over the goods referred to in the caput may be required, under the terms established in a normative act of the Federal Revenue Service of Brazil.
According [5, 8, 9], in principle, cargo unit would be free from customs clearance, but Federal Revenue understands container customs clearance is necessary, submitting it to temporary and automatic admission regime.

The temporary admission regime is governed by terms of Normative Instruction n. 285 of January 14, 2003, which provides for special customs regime for temporary admission, as follows:

Art $1^{\circ}$. Allows the importation of goods must remain in country for a fixed period, with total suspension of partial suspension payment, in case of in manner and under conditions set forth in this Instruction Normative.

In the temporary admission occurs the generating event, but its payment is suspended, until product returns to outside. In specific case of load (container), it does not need to go back to outside, since it is use in domestic transport in Brazil, including no return date.

With this analysis, it is inferred that, because it does not have container packing classification, its equipment, such as flexitank, are also not subject to such classification, being necessary legal concept for this particular equipment, given increase of its use and feasibility.

\subsection{Flexitank Life Cycle Analysis}

The growing recognition by international freight transport organizations of flexitanks benefits in liquid bulk operations proves their life cycle is advantageous for widespread use, as mentioned earlier on loading and unloading process with this equipment. If preserve its use throughout this product life cycle.

The manufacturers, vendors or responsible persons carry out loading and unloading procedure and in sequence this has been discarded.

According to [4, 5], flexitank is composed of material with PVC or polyethylene, being a thermoplastic, which proposes its reuse or recycling, and in current life cycle it is discarded.

There is a need to manage this product life cycle along supply chain, from obtaining and supplying raw material to use and disposal of product, forming set of elements that should consider sustainable development in operation.

In its logistics chain, it is observed effort in products development with use of components and processes of low environmental impact. Flexitank manufacturers are among purpose of maximizing profit and minimizing total negative environmental impacts on transactions in this material.

[10] proposed eco-efficiency concept, which analyzes ability to measure economic activity evolution in an environmentally sustainable way, through use of a formula. Efficiency (EM) measures are obtained by relationship between value of the product indicator/ service (V) and environmental influence caused by generation of product or service (EI) use:

$$
\mathrm{MS}=\mathrm{EI} / \mathrm{V}
$$

The product / service indicators are p. ex. quantity produced, net sales, and financial prices and costs. The 
indicators of environmental influence are energy consumption, greenhouse gas emissions, natural resources use, as well as recycling and reuse of product, thus composing its life cycle.

According to $[4,5]$, there are disposable versions of thermoplastic tank, but in general they are largely reusable. While it can be washed, it is highly recommended its exclusive use to a single type of product to be transported in order to avoid contamination.

As for flexitank advantages in its life cycle, there is greater availability and transportation, lower manufacturing and operation costs, reusability, ease of handling and less environmental impact, because it is made from completely recyclable material.

\section{Conclusion}

The discussion on instruments used for products transport becomes more necessary on legal parameter for market innovations, especially in recent years, with exacerbated increase in freight transport.

Certainly container is a solution facilitates this cargo flow movement, and it is clarified this was developed as a solution for materials joining, not as packaging, because legal support defines it as unitization equipment only, so its equipment Are considered accessories for unitization, and cannot be characterized as packaging either.

Law n. 6118/98 updates Law n.6288 / 75 in order to expedite container use as a cargo unit, but its legal definition is not included in this law, which certainly contributes to conceptual confusion over its equipment's. There is still no need to deal with packaging, but there is a need for instruments development to deal with innovations in freight transport market, especially regarding unitization criteria.

However, it is necessary legal definition analyze of flexitank, considered as an alternative for transporting bulk products within container that requires a legal analysis regarding its use and disposal in a sustainable way, providing for situations such as reuse or recycling, through legal characterization of flexitank life cycle will certainly favor environment and international maritime law in containerized cargo transportation.

There is no norm to be seen on flexitank disposal, what is presented is it constitutes a solution as unitization, and it is disposable to not generate contamination in products by waste of previous movement.

It is necessary to discuss flexitank as container equipment or accessory and extent of responsibility for its use, recycling and disposal, as well as for harmonization entry into each national space and integration into international logistics cycle.
This debate is limited from a legal point of view and international law regarding impact of environment disposal, which can be reused or recycled for later use, thus ensuring sustainability in life cycle as a sustainable solution in loads transport.

The specific law pertinent to theme in Brazil is old and incipient, and it is necessary to develop a set of legal instruments to include diversity of solutions with flexitank use and its classification, as well as legal instruments encourage sustainability involving cargo transportation with greater specificity.

\section{References}

[1] E. B. Weiss, "Intergenerational equity: a legal framework for global environmental change”, In: E. B. Weiss. Environmental change and international law: new challenges and dimensions, United Nations University Press, 1992.

[2] F. Barroso Garcia, Process control of operating cranes at the container termina, Universidade Carlos III de Madrid, repositório, 2012, Available in: http://hdl.handle.net/10016/16587. Access in: 21/05/2017.

[3] G. Bohács, I. Frikker, Gabor Kovács, Intermodal logistics processes supported by electronic freight and warehouse exchanges. Transport and Telecommunication, vol.14, n. 3, 2013, pp.206-213.

[4] J. E. M. Marin, Optimización de la logística de contenedores vacíos. Estudio de costes y beneficios para las navieras. 2013. Escuela Técnica Superior de Náutica. Universidad de Cantabria.

[5] A. M. Díez, C. E. Muñoz, J. M. Marín, Manual del Transporte maritime. 2. ed. Cantabria: Marge Books, 2016.

[6] World Commission on Environment and Development, Our Common Future. 2 ed. Rio de Janeiro: FGV, 1991.

[7] I. Sachs, Caminhos para o desenvolvimento sustentável. 3 rd ed. Rio de Janeiro: Garamond, 2008.

[8] Port Review, Uso de isotank e flexitank tem demanda aquecida no Brasil. Available in: http://www.revistaportuaria.com.br/noticia/18590. Access in: $21 / 05 / 2017$

[9] O. A. Castro Junior, P. Fabris. Aspectos jurídicos do contêiner. Revista Eletrônica Direito e Política. Programa de Pós-Graduação Stricto Sensu em Ciência Jurídica da UNIVALI, Itajaí, vol. 6, n. $1,1^{\circ}$ quadrimestre de 2011.

[10] J. Bloemhof, J. Van Nunen, "Integration of Environmental Management and SCM", Erasmus Research Institute of Management, Rotterdam, 2005. 